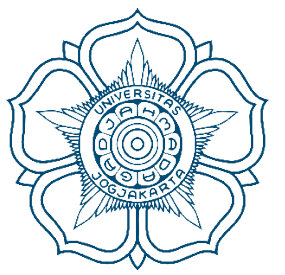

Tittle

: THE CRIMINAL LIABILITY OF CORPORATE TAXPAYER IN THE PERSPECTIVE OF TAX LAW REFORM IN INDONESIA

Author

: Henry Dianto

MIMBAR HUKUM

DOI $\quad:$ http://doi.org/10.22146/jmh.17638

Publisher : Faculty of Law Universitas Gadjah Mada

URL : jurnal.ugm.ac.id/jmh

E Issn : :2443-0994

P Issn : :0852-100x 


\title{
THE CRIMINAL LIABILITY OF CORPORATE TAXPAYER IN THE PERSPECTIVE OF TAX LAW REFORM IN INDONESIA
}

\author{
Henry Dianto Pardamean Sinaga*
}

Regional Tax Office of West Kalimantan

Jalan Jenderal Ahmad Yani No. 1, Pontianak, West Kalimantan, 78124

\begin{abstract}
The raise of tax evasion by corporation in Indonesia has been very detrimental to the state revenue, so it is required the solution to tackle it through the existing criminal liability doctrine. This article generates that corporate and/or human can be accounted for either jointly or individually in tax crime undertaken of the corporate taxpayer by affirming the element of "any person" and strict liability article within the framework of the future tax law reform. Furthermore, in absentia investigation of the corporate taxpayer crime could be filed as long as fulfilling formil and material requisites.
\end{abstract}

Keywords: taxpayer, corporate, liability, administrative, penalty.

\section{Intisari}

Maraknya penggelapan pajak Wajib Pajak Badan di Indonesia sangat merugikan pendapatan negara sehingga diperlukan alternatif penanggulangannya melalui doktrin pertanggungjawaban pidana yang ada. Disimpulkan bahwa badan hukum dan/atau manusia dapat dipertanggungjawabkan baik bersama-sama atau sendiri-sendiri dalam pidana yang dilakukan Wajib Pajak Badan dengan menegaskan unsur "setiap orang" dan adanya pasal tanggung jawab mutlak dalam kerangka pembaharuan hukum pajak. Selain itu, penyidikan in absentia Wajib Pajak Badan di Indonesia dapat diberkaskan dengan tetap memenuhi syarat formil dan materiil.

Kata Kunci: wajib pajak, badan, pertanggungjawaban, administrasi, sanksi.

\section{Pokok Muatan}

A. Introduction 544

B. Discussion

1. The Criminal Liability for Person and Legal Entity in Corporate Taxpayers Crimes in Indonesia

2. The Investigation In Absentia in Tax Crime Committed by Corporate Taxpayer in Indonesia .. 552

C. Conclusion 554 


\section{A. Introduction}

The role of Corporate Taxpayer towards the tax revenue has not been well-implemented yet in Indonesia, since there are so many tax evasions such as certain abuse on legal entity, either in international level or national level. One of the international cases which is quite phenomenal is "panama papers" scandal that revealed 11,5 million documents in over 50 states (including Indonesia) for the establishment of thousand offshore companies in 21 tax heavens states created by company service provider, Mossack Fonseca. ${ }^{1}$ Moreover, the biggest case in national level up until today is the tax evasion of tax manager AAG which is detrimental to the state revenue as much as IDR 1,25 trillions and more than IDR 2,5 trillions for the criminal charge. ${ }^{2}$

Rampant tax evasion committed by Corporate Taxpayer shows that the criminal liability is nearly never being implemented in the investigation of tax evasion in Indonesia. Whereas, tax authority, Tax General Directorate (TGD), are able to conduct a review on court decision such as cassation verdict of Supreme Court number 2239 K/PID.SUS/2012 which has enacted that the burden of liability for a worker in a corporate to the corporate has to be implemented simultaneously as a reflection of respondeat superior or vicarious liability doctrine. Furthermore, TGD is able to review Act that has a nature of administrative penal law which governs legal entity as a subject of law as regulated under Prevention and Eradication of Money Laundering Act, ${ }^{3}$ Corruption Eradication Act ${ }^{4}$ and Environmental
Protection and Management Act. ${ }^{5}$ Although, some Acts have insisted that legal entity is a subject of law, there is a difficulty in implementing criminal liability since there is an opinion confirmed that: (a) a crime constitutes deliberateness or wrongdoing can be committed by human (natuurlijk person), not by legal entity (rechtspersoon); ${ }^{6}$ (b) the definition of 'any person' does not reflect the scope of legal entity as a subject who committed crime that can be criminally charged; ${ }^{7}$ and (c) the controversial issue on legal entity which is questioning whether it is real or fiction or just a group of people who are bound by a contract. ${ }^{8}$

Regarding the criminal liability of tax in Indonesia, there is a structure of Tax Subject which covers Domestic Tax Subject and International Tax Subject that can cause problem in criminal liability of Corporate Taxpayer, especially for certain holding company that establishes some companies, for the purpose of hiding its assets through the company branches and reduce the tax payment through affiliated company in tax havens states. ${ }^{9}$ However, it would be a problem about the presence of the owner and/or the executive board of the company with regards to the investigation of tax evasion. Nevertheless, under Indonesia's justice system, the existence of the accused or witnesses before the court is important since it deals with human rights for the accused to prove that he/she is not found guilty.

Considering that tax is a compulsory contribution to the state that is required by $\mathrm{Act}^{10}$ however,

The International Consortium of Investigative Journalists, "Panama Papers the Power Players", https://panamapapers.icij.org/the power players/, accessed on 15 August 2016.

Supreme Court Decision of Republic Indonesia number 2239 K/PID.SUS/2012, 18 December 2012.

Article 1 point (10) Law Number 8 of 2010 regarding Prevention and Eradication Money Laundering (State Gazette of the Republic of Indonesia Number 122 of 2010, Supplement to State Gazette of the Republic of Indonesia Number 5164).

Article 1 point (1) Law Number 20 of 2001 regarding Corruption Eradication Act (State Gazette of the Republic of Indonesia Number 134 of 2001, Supplement to State Gazette of the Republic of Indonesia Number 4150).

Article 1 point (32) Law Number 32 of 2009 regarding Environmental Protection and Management (State Gazette of the Republic of Indonesia Number 140 of 2009, Supplement to State Gazette of the Republic of Indonesia Number 5059).

Muladi and Dwidja Priyatno, 2010, Pertanggungjawaban Pidana Korporasi, Kencana, Jakarta, p. 46.

Romli Atmasasmita, 2013, Buku 1 Kapita Selekta Kejahatan Bisnis dan Hukum Pidana, Fikahati Aneska, Jakarta, p. 176.

Munir Fuady, 2013, Teori-Teori Besar (Grand Theory) dalam Hukum, Kencana, Jakarta, p. 185.

Ian Ramsay and Geof Stapledon, "Corporate Groups in Australia", http://law.unimelb.edu.au/_data/assets/pdf_file/0017/1710260/150CorporateGroupsResearchReport1.pdf, accessed on 16 August 2016.

10 Article 1 point 1 Law No. 6 of 1983 regarding General Requirement and Tax Procedure as being amended by Law No. 16 of 2009 regarding The Enactment of Government Regulation replaced Law No. 5 of 2008 regarding Fourth Amendment of Law No. 6 of 1983 regarding General Requirement and Tax Procedure becomes Act. 
there is a tendency that legal entity is used for tax evasion, whereas the spirit of countering tax evasion is similar with the treatment of corruption and money laundering which copes to secure the state's wealth, as well as considering tax law as a part of administrative law so that there are two main research problems in this article. First, what is the criminal responsibility of person (natuurlijk person) and legal entity (rechtpersoon) for Corporate Taxpayer in Indonesia? Second, how the procedure of an investigation in absentia in tax crime committed by corporate taxpayer in Indonesia within the system of administrative penal law?

\section{B. Discussion}

1. The Criminal Liability for Person and Legal Entity in Corporate Taxpayers Crimes in Indonesia

The law aims to maintain justice by way of managing people's behavior ${ }^{11}$ under the fundamental principle of positive law called as subject of law ${ }^{12}$ (persoon) who has the sovereignty as a right holder, namely person and legal entity. ${ }^{13}$ Legal entity as a subject of law does not apart from Organ Theory that is mentioned by Otto van Gierke and L.C Polano who explained that legal entity is a tangible thing (not fiction) in law as well as personality in a person who has their own desire and willingness through their instruments such as caretakers and members. Thus, the decision made by the caretakers and/or members is considered as the willingness of the legal entity. ${ }^{14}$ This is also confirmed by C.S.T
Kansil who claimed that persoon means right holder whereas legal entity constitutes a group of people who obtain a status from the law as persoon so that it has rights and obligations like a person. ${ }^{15}$ Therefore, even if the law determines that a person recognized as a right and obligation holder, however the law is able to exclude certain group of people as a subject of law. If the law has determined, then it is impossible for certain people to be the right and obligation holder. ${ }^{16}$

With regards to the legal entity as a subject of law in positive law in Indonesia, Act Number 40 of 2007 regarding Limited Liability Company insisted that company is a legal entity, ${ }^{17}$ which its establishment has to be done by two persons ${ }^{18}$ or more, who can act as a subject of law and have the wealth that is separated from the personal wealth of the executive boards..$^{19}$ Moreover, in the context of tax law, there is a need of understanding for who can carry out the rights and obligations of tax (subject of tax) since not all of the applicable Tax Law in Indonesia outlining explicitly about the subject of tax. This is because it is only Act Number 36 of 2008 which confirmed that the subject of tax is as a domestic subject of tax and international subject of tax which covers person, inheritance that has not been distributed yet, entity and permanent business,${ }^{20}$ meanwhile Act of General Requirement and Tax Procedure only stipulates the definition of Taxpayers, ${ }^{21}$ Act Number 42 of 2009 (Act of Value Added Tax) only governs the definition of Taxable Employers, ${ }^{22}$ and Act Number 19 of 2000 ( Act of

\footnotetext{
11 Mochtar Kusumaatmadja, et al., 2009, Pengantar Ilmu Hukum: Suatu Pengenalan Pertama Ruang Lingkup Berlakunya Ilmu Hukum, Alumni, Bandung, p. 76.

Ibid., p. 80.

E. Utrecht (terj. Moh. Saleh Djindang), 1989, Pengantar Dalam Hukum Indonesia, Sinar Harapan, Jakarta, p. 264.

Jimly Asshiddiqie, "Badan Hukum”, http://www.jimly.com/pemikiran/view/14, accessed on 23 April 2009.

C.S.T. Kansil, 1989, Pengantar Ilmu Hukum dan Tata Hukum Indonesia, Balai Pustaka, Jakarta, pp. 117-118.

Satjipto Rahardjo, 2006, Ilmu Hukum, Citra Aditya Bakti, Bandung, p. 67.

Article 7 point (6) The Law of Limited Liability Company stated that the status of legal entity in a company can only be obtained after its deed establishment is legalized by the Ministry of Law and Human Rights.

18 The Elucidation of Article 7 Point (1) of The Law of Limited Liability Company stated that the word "person" as per person, either as a citizen of Indonesia or foreigner or Indonesian legal entity or foreign legal entity.

19 Article 1 point (1) of Law No. 40 Year 2007 concerning Limited Liability Company (State Gazette of the Republic of Indonesia Number 106 Year 2007, Supplement to State Gazette of the Republic of Indonesia No. 4279).

20 Article 2 point (1) and point (3) of Law No. 36 Year 2008 concerning Income Tax (State Gazette of the Republic of Indonesia Number 133 Year 2008, Supplement to State Gazette of the Republic of Indonesia No. 42893).

21 Article 1 point (2) Law of General Requirement and Tax Procedure stated that Taxpayers is a person or legal entity, which covers tax payment, tax cut and tax collection who has the rights and obligation in tax as stipulated under Tax Law.

22 Taxable Employers as an employer who renders the taxable goods and/or taxable service which is imposed tax based on Act of Value Added Tax.
} 
Billing Tax to the Letter of Force $)^{23}$ which only defines Taxpayers. By understanding the subject of tax in Tax Law, thus as confirmed by Act of General Requirement and Tax Procedure, is that Corporate Taxpayers who has fulfilled the subjective and objective requirements is obliged to fill and render the Notification Letter (Surat Pemberitahuan $(S P T)$ ) which must be correct, complete and clear and must be signed by the executive boards or board of director or a person who has a letter of attorney. ${ }^{24}$ Therefore, under article 32 point (1) and (2) of General Requirement and Tax Procedure Act determined that the representative of the taxpayer is responsible jointly ${ }^{25}$ towards the taxable payment, by the executive boards. ${ }^{26}$

After understanding about the subjective and objective requirements as Corporate Taxpayer, further it requires the understanding about the position of tax law in ensuring that there is a legal certainty and law enforcement. C.S.T Kansil and Rochmat Soemitro affirmed that tax law is a part of Administrative Law which cannot be apart from other parts of law such as civil law and criminal ${ } \mathrm{w}^{27}$ in which contains administrative sanction (in the form of interest and or goods) and criminal sanction. ${ }^{28}$ Then, the legal certainty as a part of administrative law in which attaches the concept of grundnorm ${ }^{29}$ as a system of law which emphasizes a hierarchy of law where a law must refer to higher provision. Thus, the imposition of sanction, especially criminal sanction in tax in Indonesia must refer to fundamental norms of Pancasila that governs under article 23A of The 1945 Constitution $^{30}$ followed by other provisions under the articles of Tax Act such as Article 38, Article 39, Article 39A, Article 41, Article 41A, Article 41B, Article 41C, Article 43 of General Requirement and Tax Procedure Act and Article 41A of Billing Tax to the Letter of Force Act.

Furthermore, about tax crimes in Indonesia, generally, it must fulfill the doctrine of mens rea and actus reus with referring to the legality principle where some actions are prohibited and culpability principle where a person can be criminally charged. The legality principle has an instrumental function (no criminal acts which cannot be sued) and protection function (no criminal charge except it governs under applicable law) ${ }^{31}$ which means no prohibited acts and charged for criminal sanctions if it is not regulated under certain Act, cannot be an analogy and non-retroactive. ${ }^{32}$ Meanwhile, the principle of culpability, or it can be called as "no criminal charge if there is no proof of guilty", affirmed that a person is not allowed to be criminally charged except he/she found guilty due to their intention or their omission (culpa) have committed crimes, either being the subject (active) or not commit (passive) which is criminally charged under the Act, ${ }^{33}$ or with other words, in general sense, the doer has to be found guilty that covers

23 Article 1 point (28) of General Requirement and Tax Procedure Act and Article 1 point (3) of Billing Tax to the Letter of Force Act defines Taxpayer as a person or entity who is responsible for tax payment.

24 Article 4 of Law No. 28 Year 2007 concerning General Requirement and Tax Procedure (State Gazette of the Republic of Indonesia Number 85 Year 2007).

25 Regarding joint responsible, the elucidation of article 32 point (2) of General Requirement and Tax Procedure Act stated that there is an exemption that can be considered by Director General of Tax if the representative of taxpayer can prove and convince that in its position, based on reasonableness and appropriateness, is impossible to be responsible.

26 The elucidation of Article 32 of (4) General Requirement and Tax Procedure Act elaborates about the definition of executive boards as a person who has the authority in determining policy and/or making decision with regards to run company's activity, such as signing contract with third party, signing check, etc. even though such person's name is not on the list of executive boards in the deed of establishment or its amendment. Such provision is applicable for commissioner and majority shareholders.

27 C.S.T. Kansil and Christine S.T. Kansil, 2007, Latihan Ujian: Pengantar Hukum Indonesia, Sinar Grafika, Jakarta, p. 345.

28 Rochmat Soemitro, 1992, Pengantar Singkat Hukum Pajak, Eresco, Bandung, p. 31.

29 Bryan A. Gardner, 2004, Black's Law Dictionary, Thomson West, Amerika Serikat., p. 723. Grundnorm = basic norm. Then, it's said that "In the legal theory of Hans Kelsen, the law from which all the other laws in a society derive", p. 1086.

30 Article 23A Fourth Amendment of the 1945 Constitution stated that "tax and other retribution has a nature of force for the shake of state's purpose stipulated by Act."

31 D. Schaffmeister, et al., 2007, Hukum Pidana, Citra Aditya Bakti, Bandung, p. 7.

32 Moeljatno, 2008, Asas-Asas Hukum Pidana, Rineka Cipta, Jakarta, pp. 27-28.

33 Nurturing Body of National Law and Human Rights of The Republic of Indonesia, "Draft Naskah Akademik Rancangan Undang-Undang Tentang Kitab Undang-Undang Hukum Pidana (KUHP)”, http://www.bphn.go.id/data/documents/naskah_akademik_tentang_kuhp_ dengan_lampiran.pdf, acceesed on 27 May 2016. 
all the elements for a person has the capability to be responsible, the wrong done in narrow sense covers the omission or intention, and it can be criminally charged, ${ }^{34}$ as it is confirmed under the Article 38 of the Draft of Penal Code 2015-2016. ${ }^{35}$

With regards to criminal responsibility, a legal entity as a subject of penal law apparently can cause a problem, especially in determining mens rea as a requirement of a certain subject of law can be criminally charged since the Indonesian Penal Code $(K U H P)$ still governs the one who can commit a crime and be responsible is a person, as Van Hamel and Simons mentioned that the criminal responsibility is a condition where a certain normal psychic at a person who can receive objective disapproval in a crime in order to fulfill the requirement of a person can be criminally charged due to such act. ${ }^{36}$ The problem of classic crime that always focuses on individual act that is not able to prevent and anticipate its relation with legal entity crime, should be able to anticipate by way of imposing sanction such as incurring deterrence effect for instance, fine, retribution and rehabilitation, ${ }^{37}$ or even it can be additional charge such as announcement of court decision, total or partial closing down of legal entity, administrative measure such as total or partial revocation of certain facility and discipline measure such as placing the entity under the supervision of the authority, and or civil sanction (compensation). ${ }^{38}$ The relation between individual act and legal entity can be seen from the contractual relationship between the legal entity and its employee in working environment, so that imposing criminal responsibility on legal entity constitutes one of compelling instrument for legal entity in enacting the guideline and effective control towards its employee ${ }^{39}$ as regulated under the standard operation procedure, organizational structure and manual flow chart.

Besides, the imposition of criminal sanction on legal entity in order to be effective, it must be supported by some factors such as the level of loss in society, the involvement of company management, duration, frequency of customers, the intention to disobey, the record of serious crimes committed by the company, the possibility to prevent and the level of cooperation manifested by the company ${ }^{40}$ This is in line with the opinion of Etty Utju R. Koesoemahatmadja who claimed that legal entity constitutes a subject of law that can be imposed criminal charge such as civil sanction or administrative that is beneficial for the state including the victims by adapting the condition and its position with regards to such unlawful act. ${ }^{41}$ Therefore, if the legal entity can be criminally charged, it aims for: ${ }^{42}$ (a) generating deterrent effect for a company or shareholder since if it is only the director who is criminally charged, the company/ shareholder is still be able to run the business without any consequence as it can just change the director; (b) fine or huge compensation should be covered by company, as the director earns money from the company; and (c) avoiding to enrich themselves without any legitimize rights.

Actually, the importance of criminal responsibility on legal entity has enshrined implicitly under Article 59 of $K U H P$. However, it governs explicitly in the form of the Draft of $K U H P$

E. Utrecht, Op. cit., pp. 391-392.

35 Ministry of Law and Human Rights, "Rancangan Undang-Undang Tentang KUHP”, http://peraturan.go.id/rancangan-undang-undangtentang-kitab-undang-undang-hukum-pidana-1.html, accessed on 26 Mei 2016. Article 38 of the Draft of Penal Code 2015-2016 stated that no one can be criminally charged without fault which covers the capability to be responsible, intention or omission and no excuses.

36 Ministry of Law and Human Rights, "Rancangan Undang-Undang tentang Kitab Undang-Undang Hukum Pidana", http:/peraturan.go.id/ rancangan-undang-undang-tentang-kitab-undang-undang-hukum-pidana-1.html, accessed on 26 May 2016.

37 Cristina de Maglie, "Models of Corporate Criminal Liability in Comparative Law", http://openscholarship.wustl.edu/cgi/viewcontent. cgi? article $=1213 \&$ context $=$ law_globalstudies, accessed on 30 May 2016.

38 Muladi and Dwidja Priyatno, Op. cit., p. 162.

39 Michael G. Faure et al., "Law and Economics of Environmental Crime: A Survey", http://citeseerx.ist.psu.edu/viewdoc/download?doi=10.1. 1.549.9704\&rep $=$ rep $1 \&$ type $=p d f$, accessed on 18 August 2016 .

40 Clinard, et al., in Muladi and Dwidja Priyatno, Op.cit., p. 20.

41 Etty Utju R. Koesoemahatmadja, 2011, Hukum Korporasi: Penegakan Hukum terhadap Pelaku Economic Crimes dan Perlindungan Abuse of Power, Penerbit Ghalia Indonesia, Bogor, p. 56.

42 Munir Fuady, 2002, Hukum Perusahaan: Dalam Paradigma Hukum Bisnis, Citra Aditya Bakti, Bandung, pp. $201-202$. 
2015-2016 ${ }^{43}$ for crimes committed by legal entity generally and article 118 point (2) the Draft of General Requirement and Tax Procedure Act ${ }^{44}$ for tax crimes.

According to Indonesia's Tax Law regulated under General Requirement and Tax Procedure Act and Billing Tax with the Letter of Force, it always emphasizes to for those or whoever with the elements of "due to omission" or "intentionally" thus it can be said that tax criminal charge is based on culpability principle. Therefore, it needs to have another alternative counter measure by way of adopting some doctrines such as strict liability, vicarious liability and piercing the corporate veil in anticipating the widespread of tax crimes committed by Corporate Taxpayer.

The doctrine of strict liability (absolute responsibility) is a criminal responsibility which based on Act, whether the entity violates the law or not due to fulfilling the obligation/condition/ situation regulated by Act. ${ }^{45}$ Then, Harvey Wallace et al., ${ }^{46}$ and Lucy Jones ${ }^{47}$ explained that the principle of responsibility can be applied without proving that there is fault based on some reasons such as obeying the laws for the purpose of social welfare, it is difficult to prove mens rea (the intention to act) in violation of social welfare, and there is a social jeopardy that may occur from such action. ${ }^{48}$ Even though strict liability is a form of responsibility towards the wrongdoers without proving their crimes, yet, the criminal responsibility is still based on wrongdoing since it still exists as long as it fulfills the elements of an offense but it does not have to be proven, ${ }^{49}$ as stated under Article 88 of Protection and Environmental Management Act $^{50}$ and Article 39 point (1) the Draft of KUHP 2015-2016. ${ }^{51}$

Further, Romli Atmasasmita asserted that the principle of absolute responsibility is not applicable for serious crimes instead of violating other people's rights which can be charged and the requirement of mens rea is not necessarily to be proven because it can hamper the aims of the Act. ${ }^{52}$

The application of strict liability in tax law in some states, may trigger pro and cons. The pro for strict liability is based on complexity of economic substance doctrine which involves very complex transaction structure that can only be accessed and understood taxpayer that may cause the needs of expert opinions when it comes to the dispute settlement. Therefore, there is a need of deterrence effect for tax payer such as imposing very strict sanction against the transaction that is not supported with economic substance. Meanwhile, the critics for strict liability asserted that this doctrine cannot be applicable in $\operatorname{tax}^{53}$ since the sanctioned that is imposed on persons is not in line with the general purpose of criminal sanctions and it is in contrary with the standard of criminal sanction in which is

43 Nurturing Body of National Law Ministry of Law and Human Rights of Republic of Indonesia, Op.cit. p. 35. Formulated that crimes committed by legal entity can be criminally charged together with executive boards if he/she has an important position and/or persons who have functional position in organizational structure either individually or on behalf of legal entity based on working relations or other relations within its legal entity.

44 Article 118 point (2) General Requirement and Tax Procedure stated that criminal sanction imposes against entity if the tax crimes: (a) committed or commanded by an executive board; (b) conducted in the purpose of fulfilling the vision and goals of the entity; (c) conducted based on duty and function of the commander; and (d) conducted for the purpose of bringing benefits for the company.

45 Barda Nawawi Arief, 2010, Kapita Selekta Hukum Pidana, Citra Aditya Bakti, Bandung, p. 251

46 Harvey Wallace and Cliff Roberson, 2012, Principles of Criminal Law, Pearson Education, New Jersey, p. 45, said that "strict liability" because "mere proof that the act was committed is sufficient to convict an individual. No culpability or state of mind need be proven."

47 Lucy Jones, 2013, Introduction to Business Law, Oxford University Press, Oxford, p. 344. Affirmed that "However, there are some torts, called strict liability torts, that impose liability on a person even though they have not been at fault in any way."

48 Etty Utju R. Koesoemahatmadja, Op. cit., pp. 66-67.

49 Chairul Huda, 2008, Dari Tiada Pidana Tanpa Kesalahan Menuju Kepada Tiada Pertanggungjawaban Pidana Tanpa Kesalahan: Tinjauan Kritis Terhadap Teori Pemisahan Tindak Pidana dan Pertanggungjawaban Pidana, Kencana, Jakarta, pp. 86-87.

50 Article 88 of Law No. 32 Year 2009 concerning Protection and Environmental Management Act regulated that every person who has their behaviour, business, and or activity using hazardous and toxic waste, producing and/or managing hazardous and toxic waste, and/or occurring a serious threat to the environment, is responsible for all the loss occurred without proving the elements of fault.

51 Article 39 point (1) the Draft of KUHP 2015-2016 said that: "For certain of crimes, this Act is able to determine that a person can be criminally charged for solely duet o all the fulfillment the elements of crime without taking into account that there is fault."

52 Romli Atmasasmita, 2009, Perbandingan Hukum Pidana Kontemporer, Fikahati Aneska, Jakarta, pp. 102-103.

53 Mik Shin-Li, "Strictly Wrong as a Tax Policy: The Strict Liability Penalty Standard in Noneconomic Substance Transactions", Fordham Law Review, Vol. 78, Issue 4, 2010, p. 2009 
applicable in society ${ }^{54}$ that may lead to confusion and uncertainty of tax $\operatorname{law}^{55}$ so that can cause a problem for justice, unlawful act committed by taxpayer, enforcement issue. ${ }^{56}$

Besides pro and cons of strict liability, some states have adopted directly for its tax provisions. Canada has adopted in Canadian Income Tax Act that is Article $163(1)^{57}$ and article $238 .{ }^{58}$ Article 163 (1) stated that every person is subjected to sanctions if there is an error of reporting as much as $\$ 500$, whereas article 238 stated that whoever make a mistake in reporting Notification Letter on Income Tax will be subjected to fine at the minimum $\$ 1.000$ and for the maximum $\$ 25.000$ and imprisonment for the maximum 12 months, unless the taxpayer is able to make due diligence. Meanwhile, in England, strict liability has just been applied according to Finance Act 2016 which is subjected to errors in reporting income of offshore as stipulated under the Article 106B up to $106 \mathrm{H}$ under Taxes Management Act 1970 (TMA 1970) along with the sanctions in the form of fine and/or imprisonment for maximum 51 weeks, unless the taxpayer can prove to the court that they have reliable reasons towards the wrong done in carrying such obligations of taxpayer. ${ }^{59}$

Just like another states who has applied strict liability in their tax law, actually Indonesia has adopted explicitly in the form of administrative sanction, yet, it is still implicit under its tax provision with regards to criminal sanction. Such adoption is regulated under article 7 point (1) General Requirement and Tax Procedure Act which applies administrative sanction such as fine on Notification Letter that do not convey in certain period of time, and article 16F of Added Value Tax Act which stated that the buyer of taxable goods or beneficiary of taxable service is responsible jointly with regards to tax payment, as long as they cannot show the tax payment proof. It is said that it applies implicitly because it needs certain steps to reach its implementation such as reviewing the article of tax law for then strict liability can be applied for other related parties. For instance, to the shareholders or controllers as stated under the elucidation of article 32 point (4) of General Requirement and Tax Procedure Act and the elucidation of article 7 point (1) of Limited Liability Act regarding to be responsible jointly towards the tax payment as stipulated under article 32 point (2) of General Requirement and Tax Procedure. However, this is really difficult for its implementation since there is no such affirmation in the form of Tax Act.

The doctrine of vicarious liability onto a person's fault whenever it fulfills two conditions: there is a delegation or in the sense of no delegation but the point is that such person is not doing according to his personal capacity. ${ }^{60}$ This is also affirmed by Ewan MacIntyre ${ }^{61}$ and Reiner $\mathrm{H}$. Kraakman ${ }^{62}$ stated that the employer on behalf of his/ her employee is responsible for his/her employee's fault during carrying their duty. In Indonesia, the doctrine of vicarious liability is in the stage of ius constituendum as aspired under article 39 point (2) of the Draft of KUHP 2015-2016 ${ }^{63}$ however it is way

4 Richard A. Wasserstrom, "Strict Liability in the Criminal Law", Stanford Law Review, Vol. 12, No. 4, July 1960 , p. 734.

55 Thomas C. Vanik Jr, "Torpedoing a Transaction: Economic Substance Versus Other Tax Doctrines and the Application of the Strict Liability Penalty", Cleveland State Law Review, Vol. 64, Issue 1, 2015, p. 109.

56 Kathleen DeLaney Thomas, "The Case Against A Strict Liability Economic Substance Penalty", https://ssrn.com/abstract=1794277, accessed on 2 September 2016.

57 Government of Canada, “Canadian Income Tax Act, Current to August 29, 2016”, http://laws-lois.justice.gc.ca/eng/acts/i-3.3/page-196.html, accessed on 2 September 2016.

58 Government of Canada, "Canadian Income Tax Act, Current to August 29, 2016", http://laws-lois.justice.gc.ca/eng/acts/I-3.3/page-266. html\#docCont, accessed on 2 September 2016.

59 Chapter 24 The Finance Act 2016, Offences relating to offshore income, assets, and activities.

60 Asworth in Chairul Huda, Op.cit., pp. 43-45.

61 Ewan MacIntyre, 2014, Business Law, Pearson Education Limited, Essex, p. 375.

62 Reinier H. Kraakman, "Vicarious And Corporate Civil Liability", in Michael Faure, 2009, Tort Law and Economics, Edward Elgar Publishing Limited, Glos, p. 134. Reinier H. Kraakman affirmed that the replacing responsibility as: "the absolute liability of one party - generally the legal 'principal' - for misconduct of another party - her 'agent' - the actor whose activities she directs. As such, traditional vicarious liability is a form of strict secondary liability, in contrast to secondary liability imposed on principals or other parties under a duty-based standard such as negligence."

63 Article 39 point (2) of the Draft of KUHP 2015-2016 stated that: "In terms of regulated by Act, everyone is able to be responsible for crimes committed by others." 
much different if it compares with Part 2 of article 07 Model Penal Code of the United States which provides more legal certainty as follow: ${ }^{64}$ (a) there is a minor crimes that is subjected to fine outside criminal law, and the regulator mentioned that the criminal responsibility occurs when a person acts on behalf of corporate under his/her authority as an employee; or (b) A negligence towards certain duty which is regulated under Act that must be conducted by Corporate; or (c) a crime that has been approved or conducted by commissioner or higher management who acts on behalf of the Corporate in their authority as an employee.

The application of vicarious liability has been adopted by several states under its tax law such as in India and Canada. In India, the application of this doctrine occurs within two stages that is, a corporate is criminally responsible for the infringement committed by the employee within their working environment, further, the main employees are criminally responsible for any violation committed by the corporate stipulated under article 278B Indian Income Tax Act (ITA) 1961-2016 ${ }^{65}$ stated that if a corporate commits a violation, everyone, when the violation was committed, is considered guilty and responsible, except they can prove that they are not guilty or have conducted due diligence for preventing such violation. Whereas, in Canada, the application of vicarious liability is regulated under article 160 (1c) Canadian Income Tax Act $^{66}$ which stated that a person who has received property through factious transfer or unusual (non- arm's length transfer) from a person who transfer it (transferor), considered as a party who is responsible for shifting the tax liabilities of such transferor.

With regards to vicarious liability under the tax law, Indonesia does not explicitly implement it. It means that it needs to be constructed first through stages before it implements in such context of vicarious liability. This may lead to the definition of taxpayer in the context of General Requirement and Tax Procedure Act and Income Tax Act, the taxpayer in the context of Billing Tax with the Letter of Force Act and the representative of taxpayer in the context of General Requirement and Tax Procedure Act, which its explanation is as follow: (a) the exemption of joint responsibility to the Director is on the condition where he/she is able to prove and convince that in his/her position, based on appropriateness and reasonableness, is impossible to be responsible which such joint responsible cannot be shifted to other party such as commissioner and shareholder or manager or a person (even though it is not listed under the deed of establishment or its amendment) who apparently has the authority to determine a policy and/or making decision for the company and/or having the authority to signing a contract and or signing a check, and etc; (b) the provision regarding privilege that has a correlation with Beneficial Owner ${ }^{67}$ as enshrined under article 18 point (3b), ${ }^{68}$ point (3c) $)^{69}$ and point $(3 \mathrm{~d})^{70}$ of Income Tax Act; (c) Article 13A of General Requirement and Tax Procedure Act is a follow-up of criminal sanctions in tax law for crime

64 Romli Atmasasmita, Op.cit., pp. 178-179

65 Section 278B (1) of the Indian ITA 1961-2016. See Income Tax India, "Income Tax Act", http://www.incometaxindia.gov.in/ pages/acts/income-tax-act.aspx, accessed on 6 September 2016.

66 Government of Canada, "Canadian Income Tax Act, Current to August 29, 2016", http://laws-lois.justice.gc.ca/eng/acts/i-3.3/page-191,html, accessed on 2 September 2016.

${ }_{67}$ Abdul Ficar Hadjar, et al., 2014, Menghukum Pengemplang Pajak: Hasil Eksaminasi Publik atas Putusan Mahkamah Agung dalam Perkara Tindak Pidana Pajak dengan Terdakwa Suwir Laut, The Indonesian Legal Resource Center dan Indonesian Corruption Watch, Jakarta.

68 Article 18 point (3b) of Income Tax Act stated that a tax payer who purchase shares or assets of a company through other party or entity which is established for special purpose (special purpose company) as a party who actually doing such purchase as long as the taxpayer has the preferential relationship with other party or such entity and there is an unusual price.

69 Article 18 point (3c) of Income Tax Act which regulates that the sales or shares transfer of a company between conduit company or special purpose company that is established or based in Indonesia or Permanent Business Establishment (Bentuk Usaha Tetap (BUT)) in Indonesia can be determined sales or share transfer of a company that can be considered as as a sales of shares transfer of company which based in Indonesia or $B U T$ in Indonesia.

70 Article 18 point (3d) of Income Tax Act regulates that the amount of income earned by the domestic taxpayer from the employer who has the privilege with other company which is not established and not based in Indonesia, can be determined again, in terms of the employer shifts the whole or part of taxable income into the form of expense or other expenditures that is paid to such company which is not established and not based in Indonesia. 
committed by a person due to his/her omission carried out such accusation under article 38 of General Requirement and Tax Procedure Act in which article 13A fulfills the principle of vicarious liability that is every person who meets the accusation becomes the responsibility of taxpayer in the form of settlement of the tax payment deficiency as well as administrative sanction the increase as much as $200 \%$ from the total amount of the deficiency tax; (d) article 44B point (2) of General Requirement and Tax Procedure Act shows that ultimum remidium from tax law as well as the adoption of vicarious liability for the criminal responsibility in tax law in which every person who has met the elements of accusation of article 39 point (1), point (2), point (3) and article 39A of General Requirement and Tax Procedure Act becomes the responsibility of taxpayer in the form of the settlement of tax debt with the fine as much as four times of the amount of the tax that is not or has been paid yet or should have been paid.

The doctrine of piercing the corporate veil is an imposition of responsibility to the activity of the company towards a person or other entity ${ }^{71}$ such as company organ (director, commissioner and shareholder) towards the violation committed by the company. ${ }^{72}$ However, in certain condition, there is an exemption that is the nullification of responsibility limited to the three organ of the company in line with the doctrine of piercing the corporate veil which basically explains about when a person in a company will be responsible for an obligations of legal entity. ${ }^{73}$ This further explains under article 3 point (2), article 97 point (3) and article 115 point (1) Limited Liability Company Act which burdens the responsibility to the company's organ including the joint responsibility in terms of violation occurred, deviation and or errors in managing the company such as not feasible capital, spending the company budgets for personal purpose, no formality that shows the existence of company, there are some elements of fraud by way of misusing the company. ${ }^{74}$

Several states have adopted the doctrine of piercing the corporate veil. In the United States, the application of this doctrine can be seen under article 6672 Internal Revenue Code ${ }^{75}$ which asserted that the imposition of penalty towards any person who intentionally avoids their obligations for collecting, reporting and paying the tax unless the member of supervisor or director works in his/her capacity, does not involve daily in the finance operational, and does not really know about such fault. This is also regulated under Autralia's Tax Law that is under Article 8Y Taxation Administration Act $1953^{76}$ which affirms that when a company committed omission that is considered as violation of tax, a person (under whatever is called either employee ${ }^{77}$ of the company or not) who is in relation or involved in the company management will be considered committing violation of tax that can be charged based on the applicable provision.

Under the tax law and Company Act in Indonesia, the doctrine of piercing corporate veil is explicitly governed under article 32 point (1) (a) and point (4) of General Requirement and Tax Procedure Act that is in line with Article 3 point (2), Article 7 point (6), Article 97 point (2), Article 114 point (2) and Article 115 point (1) of Limited Liability Company Act meaning that the burden of responsibility of legal entity can be shifted into shareholders. Director, commissioner and other

\footnotetext{
71 Organization for Economic Co-Operation and Development (OECD), "Glossary of Tax Terms", http://www.oecd.org/ctp/glossaryoftaxterms. htm, accessed on 8 September 2016.

Bryan A. Gardner, Op.cit, p. 1184

Harshit Saxena, "Lifting of Corporate Veil", http://papers.ssrn.com/sol3/papers.cfm?abstract id=1725433, accessed on 2 June 2016.

Munir Fuady, 2002, Op. cit., pp. 61-62.

Cornell University Law School, "Internal Revenue Code of United States", https://www.law.cornell.edu/uscode/text/26/6672, accessed on 8 September 2016

76 Austlii Edu, "Commenwealth Consolidated Act", http://www.austlii.edu.au/au/legis/cth/consol_act/taa1953269/s8y.html, accessed on 9 September 2016.

77 The employee mentioned is that an officer which in relation with corporate that can be director, secretary, manager and administrator.
} 
parties. Moreover, the applicable tax law can be seen under Article 119 of the Draft of General Requirement and Tax Procedure. ${ }^{78}$

2. The Investigation In Absentia in Tax Crime Committed by Corporate Taxpayer in Indonesia

Tax law in Indonesia is a part of administrative penal law because administrative law has criminal sanction so that if the criminal offender violates the law, then he/she can be subjected to administrative sanction as well as criminal sanction. ${ }^{79}$ Further, Ridwan HR elaborated that the scope of administrative law covers government's conduct in field of public, the authority of government and all the legal consequence, as well as the law enforcement and the imposition of sanctions in government. ${ }^{80}$

The existence of criminal sanction in tax law in Indonesia asserted that the Tax Directory General has to implement the process of law enforcement well by way of upholding the principle of presumption of innocence so that the investigation of the accused party is an important stage since it assesses the material substance regarding evidence under article 184 point (1) of Criminal Procedural Law (Kitab Undang-Undang Hukum Acara Pidana $(K U H A P))$ that is explanation of the accused. Besides, the further process of investigation if when it is declared P-21 (completed), the present of the accused in the process of court hearing is important, it is regulated under Article 12 point (1) Act Number 48 of $2009,{ }^{81}$ Article 1 point (15) KUHAP, ${ }^{82}$ Article 183 of $K U H A P,{ }^{83}$ and Article 196 point (1) KUHAP.${ }^{84}$ Even Article 154 point (2), point (4) and point (6) KUHAP and Circular Letter of Supreme Court (Surat Edaran MA(SEMA)) number 6 of 1998 does not provide a space for the accused for being assessed without his/her present (in absentia) with the notification that if the suspect is not present without legitimate reasons at the determined hearing session and has been summoned lawfully thus the judge orders for the suspect get summoned once again when the summon has been conducted lawfully for twice, the suspect is presented by force in the next hearing session. The judge is even able to refuse the legal counsel who get the power of attorney from the accused who is not present in the stage of investigation in hearing session since it can hamper the process of investigation and the implementation of court decision.

Regarding in absentia justice in taxation crimes, it has been governed yet directly in lex spesialis in taxation under General Requirement and Tax Procedure Act, whereas the handling of crimes in taxation refers to the loss of states revenue in taxation that is committed by the taxpayer especially in handling tax crimes which is allegedly committed by Foreign Taxpayer such as Foreign Capital Investment (Penanaman Modal Asing $(P M A))$. This is clear that the spirit of countering tax crimes and the execution of money laundering as well as corruption have the same purpose that is to rescue the state wealth.

Besides In Absentia has not been regulated yet in tax crimes either in General Requirement and Tax Procedure Act and KUHAP, apparently the definition of tax crimes investigation is stated that the suspect must be found. ${ }^{85}$ This would make

78 Article of 119 of the Draft of General Requirement and Tax Procedure asserts that a towards an entity that is being accused with the criminal sanction such as fine, three times of the amount of fine that is charged against a person, and for the accused party who has not settled the loss of state budgets in taxation, despite being criminally charged such as fine for an entity, it is also charged for additional criminal sanction such as the payment of certain amount of money to replace the loss of state budgets in taxation.

79 Bryan A. Gardner, Op.cit, p. 399. Administrative crime as the synonym of administrative penal is defined as: "An offense consisting of a violation of an administrative rule or regulation that carries with a criminal sanction."

80 Ridwan H.R., 2007, Hukum Administrasi Negara, RajaGrafindo Persada, Jakarta, p. 44.

81 Article 12 point (1) of Act Number 48 of 2009 regarding Judicial Power stated that first instance which examines, justifies and making decision of criminal case with the present of the accused except the Act determines otherwise.

82 Article 1 point (15) KUHAP defines the accused as a suspected person who is prosecuted, assessed, and tried before the court

83 Article 183 of KUHAP stated that the judge is not allowed to impose criminal charge to a person if at least there are two valid evidences, the judge acquires belief that the crimes was committed and the accused is found guilty.

84 Article 196 point (1) KUHAP governed that the court adjudicates the case with the present of the accused except the Act says otherwise.

85 Article 1 point (31) of General Requirement and Tax Procedure Act defines the investigation of tax crimes for searching as well as collecting the evidence which by that evidence makes the crimes revealed and the suspect is found. 
burdensome for Civil Servant Investigator (Penyidik Pegawai Negeri Sipil(PPNS)) Tax General Directorate for the suspect in absentia, besides other difficulties like the process of investigation which has to go after evidence examination ${ }^{86}$ in which Article 43A point (1) General Requirement and Tax Procedure Act governs that the examination of evidence is carrying before the investigation of crimes in taxation is an authority of Tax General Directorate that is conducted based on information, data, report and complaint. The existence of certain period of time between the process of examination evidence and the investigation can be used by the suspect (especially for foreigner) for escaping to outside Indonesia. For example, there is a case about tax crime PT. AJM which has the status of Foreign Capital Investment (PMA) with the accused who is Indonesian called S a.k.a OSK, Director of PT. AJM, who has been convicted, meanwhile the suspected is foreigner namely G a.k.a KHC (who possibly has escaped), Commissioner of PT.AJM, still in P-19 (not completed yet) nevertheless, almost all the sales of PT. AJM has been transferred to the personal bank account of the suspected $G$ a.k.a KHC that was not reported under Notification Letter of PT. AJM thus it brought to the loss of state revenue for the minimum IDR 15 billion. ${ }^{87}$

Even though KUHAP does not govern about the principle of in absentia, there are some Acts that regulate specifically about criminal justice in absentia, as stipulated under Article 38 point (1) of Corruption Act, ${ }^{88}$ Article 79 point (1) of Money Laundering Act, ${ }^{89}$ and Article 79 Act Number 31 of 2004 regarding Fishery (Fishery Act). ${ }^{90}$ Whereas, in tax crime, in absentia justice has been regulated explicitly in taxation positive law as lex spesialis from $K U H A P$, however, for the purpose of restoring the loss on the states revenue as the effect of crimes in taxation that is committed by the accused thus in ius constituendum of taxation in Indonesia becomes very likely that the accused cannot be presented in the hearing session since he/she may escape or with any other reasons, however it is found that there is the suspect's wealth. ${ }^{91}$ This is clearly aspired under article 103 point (1) the Draft of General Requirement and Tax Procedure Act ${ }^{22}$ that is in line with article 38 point (1) of Corruption Act and Article 79 point (1) of Money Laundering Act which stipulated that the case can be examined and adjudicated without the presence of the accused when the accused has been summoned lawfully and is not present in the hearing session without legitimate reasons. Further, article 103 point (3) of the Draft of General Requirement and Tax Procedure added that based on the decision which is imposed to the accused without the presence of the accused, the court decision will be announced by the prosecutor on the announcement board at the court, government office or to his/her legal counsel.

Regarding in absentia justice in terms of investigation and there is no affirmation under Tax Law, Marwan Effendy claimed that the dossier of the investigation in absentia is the same with the usual dossier of other crimes prepared by the Prosecutor with all the information of the accused then to be handed to Prosecutor Researcher. Marwan Effendy suggested that the minutes of investigation (Berita Acara Pemeriksaan (BAP)) of the accused is still

86 Article 30 point (1) (a) the Regulation of Ministry of Finance Number 239/PMK.03/2014 regarding the Procedure of Evidence Examination for Crimes in Taxation.

87 Tax General Directorate, "Sidang Tindak Pidana Pajak PT. AJM", http://www.pajak.go.id/content/sidang-tindak-pidana-pajak-pt-ajm, accessed on 30 Mach 2017.

88 Article 38 point (1) Corruption Act stated that "In terms of the accused has been summoned lawfully and he or she is not present in hearing session without legitimate reason, thus the case can be examined and adjudicated without his/her present."

89 Article 79 point (1) of Money Laundering Act stated that "In terms of the accused has been summoned lawfully and he or she is not present in hearing session without legitimate reason, thus the case can be examined and adjudicated without his/her present."

90 Article 79 of Fishery Act as amended by Act Number 45 of 2009 stated that "The hearing session can be conducted without the presence of the accused."

91 Nurturing Body of National Law Ministry of Law and Human Rights of Republic of Indonesia "Naskah Akademik RUU Ketentuan Umum dan Tata Cara Perpajakan", http://www.bphn.go.id/data/documents/Penyelarasan-NA-RUU-Ttg-Ketentuan-Umum-\&-Tata-Cara-Perpajakan. $P D F$, accessed on 29 March 2017.

92 Ibid, p. 59, Annex of the Draft of General Requirement and Tax Procedure Act. 
to be attached since it must contain the complete identity of the accused as the formal requirement of article 143 point (2) (a) of $K U H A P$. The BAP of the accused has to be completed with the Minutes of Absence of the Accused who has been summoned lawfully such as letter to the headman, immigration office, police an up until List of Missing Person (Daftar Pencarian Orang (DPO)). ${ }^{93}$

\section{Conclusion}

According to underlying background and discussion above, there are two conclusions. First, the criminal responsibility of Corporate Taxpayer in Indonesia can be criminally responsible together and/ or independently to legal entity (rechtpersoon) and or a person (natuurlijk person) such as shareholder, director, commissioner and or other party who has the functional position in the organizational structure of Corporate Taxpayer which acts on behalf of either for individual or on behalf of Corporate Taxpayer, based on employment relationship or any other relationship in the scope of such Corporate Taxpayer, or; the burden of criminal responsibility of Corporate taxpayer can be shifted into only such naturlijk persoon, except the natuurlijk persoon can prove and convince that in their position, based on appropriateness and reasonableness, is impossible to be responsible. Regarding the criminal responsibility of rechtpersoon, the sanction is in the form of restoring the loss of states revenue as well as a raise or fine as much as or certain percentage from the unpaid tax or deficiency of tax, or the tax that should be paid. Whereas the criminal responsibility of natuurlijk persoon who has been found guilty in tax crimes, besides the imprisonment, the accused is responsible for the tax payment either individual or jointly. In terms of tax law reform, especially in law enforcement in taxation, the goal is that it can minimize tax evasion such as misuse of Corporate Taxpayer, there some opinions as follow: (1) the definition of the element of "everyone" refers to a peso or legal entity under the future Tax Law and (2) the articles under tax law, for the future, stated that tax law can determine that everyone cam be criminally charged due to the fulfillment of all the elements of crimes without takin into account the faults (strict liability) because it is effective to prevent the wrongdoer who avoid to pay the tax especially to offshore tax evasion, has been asserted by tax law.

Second, as the measure of securing the state assets, the investigation of in absentia in tax crime committed by the Corporate Tax Payer in Indonesia, can be filed and treated the same as the usual crimes prepared by the Prosecutor completed with Minutes of the Absence of accused party by fulfilling formal and material requirements. For the tax law reform, it is suggested that there will be an amendment for the definition of investigation in the scope of taxation and or articles that provide the possibility of the suspect to be absence (in investigation) or the accused (in hearing session) if all the measures are done including asset tracing.

\section{REFERENCES}

\section{A. Books}

Arief, Barda Nawawi, Kapita Selekta Hukum Pidana, Penerbit Citra Aditya Bakti, Bandung, 2010.

Atmasasmita, Romli, 2009, Perbandingan Hukum

Pidana Kontemporer, Fikahati Aneska, Jakarta.
2013, Buku 1 Kapita

Selekta Kejahatan Bisnis dan Hukum Pidana, Fikahati Aneska, Jakarta.

Effendy, Marwan, 2010, Peradilan In Absentia dan Koneksitas, Timpani Publishing, Jakarta.

Fuady, Munir, 2002, Hukum Perusahaan: Dalam Paradigma Hukum Bisnis, Citra Aditya

93 Marwan Effendy, 2010, Peradilan In Absentia dan Koneksitas, Timpani Publishing, Jakarta, pp. 28-29. 
Bakti, Bandung. , 2013, Teori-Teori Besar (Grand Theory) Dalam Hukum, Kencana, Jakarta.

Gardner, Bryan A., 2004, Black's Law Dictionary, Thomson West, US.

Hadjar, Abdul Ficar, et al., 2014, Menghukum Pengemplang Pajak, The Indonesian Legal Resource Center dan Indonesian Corruption Watch, Jakarta.

H.R., Ridwan, 2007, Hukum Administrasi Negara, RajaGrafindo Persada, Jakarta.

Huda, Chairul, 2008, Dari Tiada Pidana Tanpa Kesalahan Menuju Kepada Tiada Pertanggungjawaban Pidana Tanpa Kesalahan: Tinjauan Kritis Terhadap Teori Pemisahan Tindak Pidana dan Pertanggungjawaban Pidana, Kencana, Jakarta.

Jones, Lucy, 2013, Introduction to Business Law, Oxford University Press, Oxford.

Kansil, C.S.T., 1989, Pengantar Ilmu Hukum dan Tata Hukum Indonesia, Balai Pustaka, Jakarta. , et al., 2007, Latihan Ujian: Pengantar Hukum Indonesia, Sinar Grafika, Jakarta.

Koesoemahatmadja, Etty Utju R., 2011, Hukum Korporasi: Penegakan Hukum terhadap Pelaku Economic Crimes dan Perlindungan Abuse of Power, Ghalia Indonesia, Bogor.

Kusumaatmadja, Mochtar, et al., 2009, Pengantar Ilmu Hukum: Suatu Pengenalan Pertama Ruang Lingkup Berlakunya Ilmu Hukum, Alumni, Bandung.

MacIntyre, Ewan, 2014, Business Law, Pearson Education Limited, Essex, UK.

Moeljatno, 2008, Asas-Asas Hukum Pidana, Rineka Cipta, Jakarta.

Muladi and Dwidja Priyatno, 2010, Pertanggungjawaban Pidana Korporasi, Kencana, Jakarta.

Rahardjo, Satjipto, 2006, Ilmu Hukum, Citra Aditya Bakti, Bandung.

Schaffmeister, D., et al., 2007, Hukum Pidana, Citra Aditya Bakti, Bandung.
Soemitro, Rochmat, 1992, Pengantar Singkat Hukum Pajak, Eresco, Bandung.

Utrecht, E., 1989, Pengantar Dalam Hukum Indonesia, translated by Moh. Saleh Djindang, Sinar Harapan, Jakarta.

Wallace, Harvey, et al, 2012, Principles Of Criminal Law, Pearson Education, New Jersey.

\section{B. Journal Articles}

Vanik Jr, Thomas C., "Torpedoing a Transaction: Economic Substance Versus Other Tax Doctrines and the Application of the Strict Liability Penalty", Cleveland State Law Review, Vol. 64, Issue 1, 2015.

Shin-Li, Mik, "Strictly Wrong as a Tax Policy: The Strict Liability Penalty Standard in Noneconomic Substance Transactions", Fordham Law Review, Vol. 78, Issue 4, 2010. Wasserstrom, Richard A., "Strict Liability in the Criminal Law", Stanford Law Review, Vol. 12, No. 4, July 1960.

\section{Article in Anthology with Editor}

Kraakman, Reinier H., "Vicarious and Corporate Civil Liability", in Michael Faure, 2009, Tort Law and Economics, Edward Elgar Publishing Limited, Glos.

\section{Internet}

Asshiddiqie, Jimly, "Badan Hukum", http://www. jimly.com/pemikiran/view/14, accessed on 23 April 2009.

Badan Pembinaan Hukum Nasional Kementerian Hukum dan HAM Republik Indonesia, "Laporan Akhir Penyelarasan Naskah Akademik Rancangan Undang-Undang Tentang Ketentuan Umum dan Tata Cara Perpajakan", http://www.bphn.go.id/data/ documents/Penyelarasan-NA-RUU-TtgKetentuan-Umum-\&-Tata-Cara-Perpajakan. $P D F$, accessed on 29 March 2017.

, "Draft Naskah Akademik Rancangan Undang-Undang Tentang Kitab UndangUndang Hukum Pidana (KUHP)", http:// 
www.bphn.go.id/data/documents/naskah_ akademik_tentang_kuhp_dengan_lampiran. $p d f$, accessed on 27 May 2016.

Cornell University Law School, https://www.law. cornell.edu/uscode/text/26/6672, accessed on 8 September 2016.

Commenwealth Consolidated Act, http://www. austlii.edu.au/au/legis/cth/consol_act/ taa1953269/s8y.html, accessd on 9 September 2016.

Direktorat Jenderal Pajak, "Sidang Tindak Pidana Pajak PT. AJM", http://www.pajak.go.id/ content/sidang-tindak-pidana-pajak-pt-ajm, diakses 30 March 2017.

Faure, Michael G., et al., "Law and Economics of Environmental Crime: A Survey", http://citeseerx.ist.psu. edu/viewdoc/download?doi=10.1.1. $549.9704 \&$ rep $=$ repl\&type $=p d f$, accessed on 18 August 2016.

Government of Canada, "Canadian Income Tax Act, Current to August 29, 2016", http:// laws-lois.justice.gc.ca/eng/acts/i-3.3/page191.html, http://laws-lois.justice.gc.caleng/ acts/i-3.3/page-196.html, and http://lawslois.justice.gc.ca/eng/acts/I-3.3/page-266. html\#docCont, accessed on 2 September 2016.

Ministry of Law and Human Rights, "Rancangan Undang-Undang tentang Kitab UndangUndang Hukum Pidana", http://peraturan. go.id/rancangan-undang-undang-tentangkitab-undang-undang-hukum-pidana-1.html, accessed on 26 May 2016.

Maglie, Cristina de, "Models of Corporate Criminal Liability in Comparative Law", http://openscholarship.wustl. edu/cgi/viewcontent.cgi? article $=1213 \&$ context $=$ law_globalstudies, accessed on 30 May 2016.

Organization for Economic Co-Operation and Development (OECD), "Glossary of Tax Terms", http://www.oecd.org/ctp/ glossaryoftaxterms.htm, accessed on 8
September 2016.

Ramsay, Ian, et al., "Corporate Groups in Australia", http://law.unimelb.edu.au/ data/assets/pdf file/0017/1710260/150CorporateGroupsResearchReport1.pdf, accessed on 16 August 2016.

Saxena, Harshit, "Lifting of Corporate Veil”, $\quad$ http://papers.ssrn.com/sol3/ papers.cfm?abstract_id $=1725433$, accessed on 2 June 2016.

The International Consortium of Investigative Journalists, "Panama Papers the Power Players", https://panamapapers.icij.org/ the power_players/, accessed on 15 August 2016.

Income Tax Department of India, "The Indian Income Tax Act 1961-2016", http://www. incometaxindia.gov.in/pages/acts/incometax-act.aspx, accessed on 6 September 2016.

Thomas, Kathleen DeLaney, "The Case Against A Strict Liability Economic Substance Penalty", https://ssrn.com/abstract $=1794277$, accessed on 2 September 2016.

\section{E. Provisions}

The 1945 Constitution of the Republic of Indonesia. Indonesia Penal Code.

Law Number 8 of 1981 regarding Criminal Procedural Law (State Gazette of Republic of Indonesia of 1981 Number 76, Supplement to the Official Gazatte of Republic of Indonesia Number 3209).

Law Number 6 of 1983 regarding General Requirement and Tax Procedure as Amanded by Act Number 16 of 2009 (State Gazette of Republic of Indonesia of 2009 Number 62, Supplement to the Official Gazatte of Republic of Indonesia Number 4953).

Law Number 7 of 1983 regarding Income Tax as Amended by Act Number 36 of 2008 (State Gazette of Republic of Indonesia of 2008 Number 133, Supplement to the Official Gazette of Republic of Indonesia Number 
4893).

Law Number 8 of 1983 regarding Value Added Tax and Tax Sales of Luxury Goods as Amended by Act Number 42 of 2009 (State Gazette of Republic of Indonesia of 2009 Number 150, Supplement to the Official Gazette of Republic of Indonesia Number 5069).

Law Number 19 of 1997 regarding Billing Tax with the Letter of Force as amended by Act Number 19 of 2000 (State Gazette of Republic of Indonesia of 2000 Number 129, 295 Supplement to the Official Gazette of Republic of Indonesia Number 3987).

Law Number 30 of 2002 regarding Commission of Eradication Corruption (State Gazette of Republic of Indonesia of 2002 Number 137, Supplement to the Official Gazette of Republic of Indonesia Number 4250).

Law Number 40 of 2007 Limited Liability Company (State Gazette of Republic of Indonesia of 2007 Number 106, Supplement to the Official Gazette of Republic of Indonesia Number 4756).

Law Number 8 of 2010 regarding Prevention and
Eradication of Money Laundering (State Gazette of Republic of Indonesia of 2010 Number 122, Supplement to the Official Gazette of Republic of Indonesia Number 5164).

Law Number 31 of 2004 regarding Fishery as amanded by Act Number 45 of 2009 (State Gazette of Republic of Indonesia of 2004 Number 118, Supplement to the Official Gazette of Republic of Indonesia Number 4433).

Law Number 32 of 2009 regarding Protection and Environmental Management (State Gazette of Republic of Indonesia of 2009 Number 140, Supplement to the Official Gazette of Republic of Indonesia Number 5059).

\section{F. Court Decision}

Supreme Court Decision Number 2239 K/PID. SUS/2012 regarding Cassation Decision SL alias LCS alias A, 18 December 2012.

Tax Court Decision Number: PUT.59242/PP/M. XIIB/15/2015, 2 February 2015. 